$1 \quad \underline{\text { Title }}$

2 Bacterial Sensitivity to Chlorhexidine and Povidone-lodine Antiseptics Over Time: A Systematic

3 Review and Meta-Analysis of Human-Derived Data

5 Authors

6 Raiyyan Aftab ${ }^{1 \pi}$

$7 \quad$ Vikash H Dodhia2爪

8 Christopher Jeanes ${ }^{3}$

$9 \quad$ Ryckie G Wade W $^{4}$

\title{
11 Institutions
}

1. Department of Plastic Surgery, Portsmouth Hospitals NHS Trust, Portsmouth, UK

2. Hampshire Hospitals Foundation Trust, Winchester, UK

3. Department of Microbiology, Norfolk and Norwich University Hospital, Norfolk, UK

4. Department of Plastic and Reconstructive Surgery, Leeds Teaching Hospitals Trust, Leeds, UK

5. Faculty of Medicine and Health Sciences, University of Leeds, Leeds, UK

\section{Corresponding Author}

20 Email - ryckiewade@gmail.com (RGW) 


\section{Abstract}

Background: Surgical site infection (SSI) is the most common complication of surgery, increasing healthcare costs and hospital stay. Topical biocides such as chlorhexidine $(\mathrm{CHX})$ and povidoneiodine (PVI) are used for skin antisepsis to minimise SSIs. There is an increasing concern of developing resistance to topical biocides, however the clinical implications of this remains unclear.

Outcomes: The objective of this review was to determine whether the Minimum Bactericidal Concentration (MBC) for topical preparations of $\mathrm{CHX}$ or $\mathrm{PVI}$ have changed over time, in microbes relevant to SSI.

Methods: We searched for studies which reported the mean bactericidal concentration (MBC) of laboratory and clinical isolates of common SSI causing microbes to $\mathrm{CHX}$ and PVI. We excluded samples derived from non-humans and studies using antimicrobial solvents or mixtures of biocides with other active substances. MBC was pooled in random effects meta-analyses and change in MBC over time was explored using meta-regression.

Results: 79 studies were including, analysing 6218 microbes between 1976 and 2021. Most studies used $\mathrm{CHX}(93 \%)$ and there was insufficient data for meta-analysis of PVI. Enterobacteriales had the highest MBC for $\mathrm{CHX}\left(20 \mathrm{mg} / \mathrm{L}[95 \% \mathrm{Cl} 14,25]\right.$; ${ }^{2}$ 95\%) whilst MRSA had the lowest (3 mg/L [95\% Cl 1, 2]; $\left.I^{2} 93 \%\right)$. There was no change in MBC of $\mathrm{CHX}$ to Staphylococci ( $\beta 0.12[-1.13,1.37] ; I^{2}$ 99\%) or Streptococci $\left(\beta 0.13[-0.35,0.62] ; I^{2} 97 \%\right)$.

Conclusions: There is no evidence of change in susceptibility of common SSI-causing microbes to $\mathrm{CHX}$ over time. This study provides reassurance that the worldwide guidance that $\mathrm{CHX}$ should remain the first-choice agent for skin asepsis prior to surgery. 


\section{Introduction}

47 Surgical site infection (SSI) is the most common and costly complication of surgery $(1,2)$, occurring in approximately $5 \%$ of all surgical interventions(3). They represent an important economic burden across all surgical specialties(4), increasing hospital inpatient stay time and adversely affecting patient's mental and physical health.(4) The use of skin antisepsis prior to surgery significantly reduces the risk of SSI and consequently, post-operative morbidity and mortality(5-7).

Staphylococcus aureus and Streptococci spp. are commonly implicated microbes in SSI, along with Enterococcus spp. and Escherichia coli(8). To reduce the risk of SSI, the World Health Organisation (WHO)(7), United States of America Centre for Disease Control (CDC)(9) and United Kingdom National Institute for Health and Care Excellence (NICE)(10) recommend the application of topical chlorhexidine $(\mathrm{CHX})$ in alcohol to the planned operative site, for skin antisepsis. $\mathrm{CHX}$ in an alcoholic solvent has been shown to halve the risk of SSI following clean(11), contaminated $(12,13)$ and dirty surgery when compared to other antiseptics such as povidoneiodine $(\mathrm{PVI})$.

$\mathrm{CHX}$ is a biguanide compound, utilised both as a broad spectrum antimicrobial and topical antiseptic(14). By binding to the cell membrane and cell wall of bacteria, at lower concentrations it has a bacteriostatic effect by displacing the cations and destabilising the cell well. At higher iodine(16). When dissolved in water, iodine is released, penetrating microorganisms and oxidising proteins, nucleotides and fatty acids(17) causing cell death. Both $\mathrm{PVI}$ and $\mathrm{CHX}$ are active against gram positive and negative bacteria, fungi and viruses $(16,18)$. crisis(20). Multiple bacteria have shown reduced sensitivity (perhaps even resistance) to $\mathrm{CHX}$, particularly through multidrug resistance efflux protein qacA(19). Methicillin resistant 
75 Staphylococcus aureus (MRSA) samples with qacA/B genes showed persistent MRSA carriage

76 despite de-colonisation therapy(21). Not only is the presence of reduced sensitivity concerning, but

77 the presence of resistance conferring genes seems to be increasing annually(22). PVI resistance

78 has been less common reported(23) although this might be secondary to the multimodal effect of

79 iodine on microbes(23) or otherwise. Overall, the current state of microbial sensitivity to $\mathrm{CHX}$ and

80 PVI remains unclear.

81

82 The aim of this review is to summarise the sensitivity profiles of skin microbes (relevant to surgical

83 site infection) to $\mathrm{CHX}$ and $\mathrm{PVI}$, and explore how these have changed over time 


\section{Methods}

This review was designed and conducted in accordance with the Cochrane Handbook of Systematic Reviews(24), the protocol was published in the PROSPERO databased (CRD42021241089) and the report has been authored in accordance with the PRISMA checklist(25).

89

Types of Studies

We included all studies which reported the resistance of microbes to $\mathrm{CHX}$ or PVI based topical biocides derived from human samples. There were no language restrictions. We excluded case reports and studies which used antimicrobial solvents (e.g., alcohol) or mixtures of antiseptics (e.g. chlorhexidine mixed with cetrimide).

95

\section{Search strategy}

The NICE Healthcare Databases (hdas.nice.org.uk) was searched according to appendix 1 (supplementary materials). The medRxiv and bioRxiv preprint archives were searched with the same strategy using the R package medrxivr(26). This yielded 582 hits in PubMed, 720 in Embase, 993 in Web of Science and 896 in CINAHL. After de-duplication, there were 2318 unique citations which were screened (Fig 1). A further 3 articles were found by manual searching of these articles.

\section{Study selection}

104 Two review authors (RA and VHD) independently screened titles and abstracts for relevance, in accordance with the eligibility criteria. The full texts of potentially eligible articles were obtained and again independently assessed by the same authors. Disagreements were resolved by discussion with RGW.

\section{Data extraction}

110 Two review authors (RA and VHD) independently double extracted data. The colony was the unit 111 of analysis. Where data was missing or unclear, the corresponding author was contacted by email and if no reply was received, these values were estimated from the available data(27). 


\section{$\underline{\text { Outcomes }}$}

115 The outcome of interest was the Minimum Bactericidal Concentration (MBC). MBC was chosen over the minimum inhibitory concentration (MIC) as a measure of susceptibility because it is generally felt to be a more appropriate for topical antiseptics $(15,28)$. We were interested in deriving a pooled estimate of the MBC for different species to understand how this may have changed over time.

Methodological quality assessment

The risk of bias and methodological quality was not assessed because there are no validated tools available for studies of this nature and the study selection process ensured that only the highest quality research was included.

Missing data

After estimating some parameters, the overall rate of missing data (in the predictor variables) was

$(61 \%)$ and because this was required for the primary analyses, we imputed this data using chained equations $(29,30)$.

\section{Statistical analysis}

133 The raw data are available open-source at https://osf.io/khnb2. Using metafor(31,32), 5 studies(33-37) reporting the MBC of $\mathrm{CHX}$ for Staphylococci were identified as outliers (based on externally standardised residuals) or influential studies (based on the Cook's distance and leaveone-out values of the test statistics for heterogeneity), and their $95 \%$ confidence intervals (Cls) were far outside the $95 \% \mathrm{Cl}$ of the pooled estimate, so they were excluded from the metaanalyses. Data were then analysed in Stata/MP v16 (StataCop LLC, Texas) using the meta suite.

139 To synthesise a pooled MBC, we used a random-effects meta-analyses. We sub-grouped by the microbial family. To estimate change in MBC over time, we performed meta-regression for 
142 Staphylococci was performed, controlling for methicillin-resistance as a binary co-variate. The

143 REML estimator was used throughout. To align with calls for the abolition of $p$-values, we minimise

144 their use and avoid the term "statistical significance" $(38,39)$, instead focusing on how our findings

145 may be clinically applicable and what might explain uncertainty in the estimates. 


\section{$\underline{\text { Results }}$}

147 Ultimately, 79 studies(33-37,40-113) were included (Fig 1).

Study characteristics

150 The details of the included studies are summarised in S1 Table; readers who wish to know more 151 detail should refer to the raw data (https://osf.io/khnb2/). The included studies originated from 24 152 countries. Articles were published between 1976 and 2021, although the majority (95\%) were 153 published this century. The antiseptics used included five different $\mathrm{CHX}$ salts

154 (digluconate(33,35,37,40,47,50,55-

$58,61,63,67,69,74,75,81,83,88,90,94,97,99,101,106,107,111,113)$,

gluconate $(34,36,42,42,53,91,102,103,108,108,109,112)$, dichlorohydrate(85-87), diacetate $(71,99)$ and dihydrochloride(96)) and povidone-iodine(37,46,49,70,76,91). In total, MBC data from 6218 microbes were extracted. The microbes tested are shown in S2 Table. Most samples were laboratory isolates $(61 \%)$ and not multi-drug resistant $(88 \%)$. The reporting standards used to establish the MBC were the according to the Clinical Laboratory Standards Institute (CLSI, 67\%), International Organisation for Standardisation (ISO, 1\%).

\section{Evidence Synthesis}

The MBC of $\mathrm{CHX}$ differed significantly between the families of microbes (Fig 2). Enterobacteriales had the highest MBC for $\mathrm{CHX}\left(20 \mathrm{mg} / \mathrm{L}[95 \% \mathrm{Cl} 14,25] ; \mathrm{I}^{2} 95 \%\right)$ whilst MRSA had the lowest (3 $\mathrm{mg} / \mathrm{L}[95 \% \mathrm{Cl} \mathrm{1,} \mathrm{2];} \mathrm{I2} \mathrm{93 \% ).}$

Overall, 23 studies reported the mean MBC for Staphylococci; observations based on MSSA were more common $(41,44,51,59,61,67,68,74,88,93-95,102,106,107,110-113)$ than MRSA $(34,35,37,50,67,68,80,90,93,106,110,113)$. The pooled mean MBC of $\mathrm{CHX}$ for 
175 for resistance to methicillin (MRSA vs MSSA), there was still no evidence of a change in the MBC 176 over time $\left(\beta 0.26[-0.87,1.34] ; I^{2}\right.$ 99\%). Study level estimates for MSSA, MRSA and coagulase177 negative Staphylococci are shown in S1 Fig.

178

179 Overall, 25 studies reported the MBC of $\mathrm{CHX}$ for Streptococci species; observations of viridans 180 Streptococci were most common(44,45,47,48,52-54,58,66,69,75,77-79,81,82,84-

$18186,89,99,100,103,105,106)$ and 1 study(106) provided an estimate for Streptococcus pyogenes 182 (Lancefield group A). The pooled mean MBC of CHX for Streptococci was $8.54 \mathrm{mg} / \mathrm{L}(95 \% \mathrm{Cl}$ 4.75, $\left.18312.3 ; I^{2} 99 \%\right)$. Meta-regression showed that the MBC of CHX for Streptococci had not changed 184 over time ( $\beta 0.13[-0.35,0.62] ; I^{2}$ 97\%; Fig 4).

185

186 There were insufficient data for meta-analysis of the MBC of PVI. Also, the majority of MBC data 187 for PVI was derived from studies of Enterobacteriales, which is not a common cause of surgical 188 site infection and so equally, not clinically relevant. 
bioRxiv preprint doi: https://doi.org/10.1101/2021.1123.469660; this version posted November 23, 2021. The copyright holder for this preprint (which was not certified by peer review) is the author/funder, who has granted bioRxiv a license to display the preprint in perpetuity. It is made available under aCC-BY 4.0 International license.

\section{Discussion}

This review summarise the evidence to-date and suggests that there has been no increase in MBC of $\mathrm{CHX}$ for the main SSI-causing skin microbes in recent decades. The stability of $\mathrm{CHX}$ susceptibility is reassuring for clinicians and policy makers alike, as it endorses current surgical guidance worldwide advocates topical alcoholic chlorhexidine for skin asepsis prior to surgery.

The definition of bacterial susceptibility and resistance to biocides is still a matter of debate. Most clinically relevant bacteria have defined susceptibility and resistance to systemic antibacterials based upon the MIC relative to an epidemiologically derived clinical breakpoint. However, the use of MICs is less useful in determining the efficacy of topical antiseptics biocides given the desire to induce death of specific microbes rather than inhibition. Understanding the lethality of a biocide (hence $\mathrm{MBC}$ ) is therefore a potentially more attractive measure than MIC for topical antiseptics(114). Additionally, the relevance of both MICs and MBCs with respect to biocides has been questioned.(15) Chlorhexidine for skin prep is used in concentrations of 5000 to $50000 \mu \mathrm{g} / \mathrm{mL}$ and with $\mathrm{MBC}$ values ranging from 0 to $30 \mu \mathrm{g} / \mathrm{mL}$, this is one thousand times greater than the apparent required concentration(115).

MIC and MBC rely on attaining a steady concentration in bodily fluids as seen by the pharmacodynamics of antibiotics(116). The EUCAST definition of a susceptible organism is "a microorganism is defined as susceptible by a level of antimicrobial activity associated with a high likelihood of therapeutic success"(117). Therapeutic success in the context of topical CHX prior to surgery is disinfection; complete elimination of all relevant micro-organisms, except certain bacterial spores(118). Measurement of MIC and MBC are gained from in vitro susceptibility testing of microorganisms to topical biocides and therefore, provide little information as to the mechanism of resistance or likely clinical outcome. Therefore, our recommendation is the utilisation of epidemiological cut-off values (ECOFF) based on MBC distributions to better understand the response of bacteria to $\mathrm{CHX}$ in clinical practice. An analysis of ECOFF values of $\mathrm{CHX}$ to common bacterium, including those commonly causing SSI did not reveal a bimodal distribution, concluding that resistance is uncommon to $\mathrm{CHX}$ in natural populations of clinically relevant organisms(88). 
While values above a certain cut off may be defined as a breakpoint and hence resistant, this needs to be correlated with the clinical picture. Does $\mathrm{CHX}$ still achieve adequate disinfection in a population of bacterium with a MBC value greater than the 95\% ECOFF? Without this information, our understanding of how MBC values beyond the normal distribution impacts clinical use remains poor. However this is contrary to the application of biocides in clinical settings prior to surgery, particularly during skin preparation of sensitive areas (e.g. the face) and in the presence of open wounds(6). We speculate that real-time methods of quantifying bacterial colonisation (e.g. free bacterial DNA/RNA sequency tools such as MinilON), taken before and serially after topical application of $\mathrm{CHX}$, may be more clinically useful in understanding the true bactericidal effect of $\mathrm{CHX}$, what microbes is acts upon preferentially, how long it exerts its action and how this is achieved.

Limitations

Most of the included studies reported MIC rather than MBC, which meant that much data could not be synthesised. This might explain why our meta-data (for Staphylococci and Streptococci at least) disagrees with individual articles $(18,19,21,22)$. Papers also often failed to report the type and concentration of chlorhexidine used which hindered meta-regression. Some papers clearly stated the year that the microbial strain was isolated, although this was often unclear and therefore the date of the paper was taken as the year of the isolate which may not adequately represent the change in MBC over time. This was also the case with location, so where possible the location of the laboratory or hospital was used as a surrogate. Isolates from a clinical setting are exposed to different selection pressures. As $61 \%$ of the microbes used were laboratory isolates as opposed to clinical isolates, it is unclear how our data can be generalised to clinical environments.

\section{Conclusion}

243 There has been no demonstrable change in the susceptibility of surgical site infection causing 244 pathogens to chlorhexidine over time. A clear definition of reduced susceptibility and resistance of pathogens to biocides is needed, alongside consensus on the methods for measuring these phenomena. 


\section{Contributions}

249 RA and VHD contributed equally to this paper and are joint first authors. They co-designed the 250 protocol, extracted data and co-authored the manuscript.

251 CJ provided clinical oversight for this study, supporting the design, advising on data extraction, 252 analysis techniques and co-authored the manuscript.

253 RGW conceived the idea of this study, co-designed the protocol, supervised all elements of the 254 delivery, extracted, and checked data, performed the statistical analysis and co-authored the manuscript 


\section{References}

1. Gibson A, Tevis S, Kennedy G. Readmission after delayed diagnosis of surgical site infection: a focus on prevention using the American College of Surgeons National Surgical Quality Improvement Program. Am J Surg. 2014 Jun;207(6):832-9.

2. Zimlichman E, Henderson D, Tamir O, Franz C, Song P, Yamin CK, et al. Health CareAssociated Infections. JAMA Intern Med. 2013 Dec 9;173(22):2039.

3. Garner BH, Anderson DJ. Surgical Site Infections. Infect Dis Clin North Am. 2016 Dec;30(4):909-29.

4. Badia JM, Casey AL, Petrosillo N, Hudson PM, Mitchell SA, Crosby C. Impact of surgical site infection on healthcare costs and patient outcomes: a systematic review in six European countries. J Hosp Infect. 2017;96(1):1-15.

5. Hirsch T, Seipp H-M, Jacobsen F, Goertz O, Steinau H-U, Steinstraesser L. Antiseptics in surgery. Eplasty. 2010 May 27;10:e39.

6. Wade RG, Burr NE, McCauley G, Bourke G, Efthimiou O. The Comparative Efficacy of Chlorhexidine Gluconate and Povidone-iodine Antiseptics for the Prevention of Infection in Clean Surgery: A Systematic Review and Network Meta-analysis. Ann Surg. 2020 Sep 1 ;Publish Ahead of Print.

7. World Health Organization. Global guidelines for the prevention of surgical site infection. 2016.

8. Owens CD, Stoessel K. Surgical site infections: epidemiology, microbiology and prevention. J Hosp Infect. 2008 Nov;70:3-10.

9. Berríos-Torres SI, Umscheid CA, Bratzler DW, Leas B, Stone EC, Kelz RR, et al. Centers for Disease Control and Prevention Guideline for the Prevention of Surgical Site Infection, 2017. JAMA Surg. 2017 Aug 1;152(8):784.

10. National Institute for Health and Care Excellence (Great Britain), National Guideline Centre (Great Britain). Surgical site infections: prevention and treatment. 2019

11. Wade RG, Burr NE, McCauley G, Bourke G, Efthimiou O. The Comparative Efficacy of Chlorhexidine Gluconate and Povidone-iodine Antiseptics for the Prevention of Infection in Clean Surgery. Ann Surg. 2020 Sep 1; Published Ahead of print.

12. Chen S, Chen JW, Guo B, Xu CC. Preoperative Antisepsis with Chlorhexidine Versus Povidone-lodine for the Prevention of Surgical Site Infection: a Systematic Review and Metaanalysis. World J Surg. 2020 May;44(5):1412-24.

13. Ayoub F, Quirke M, Conroy R, Hill A. Chlorhexidine-alcohol versus povidone-iodine for preoperative skin preparation: A systematic review and meta-analysis. Int J Surg Open. 2015;1:41-6.

14. Gilbert P, Moore LE. Cationic antiseptics: diversity of action under a common epithet. J Appl Microbiol. 2005 Oct;99(4):703-15.

15. Horner C, Mawer D, Wilcox M. Reduced susceptibility to chlorhexidine in staphylococci: is it increasing and does it matter? J Antimicrob Chemother. 2012 Nov;67(11):2547-59. 
bioRxiv preprint doi: https://doi.org/10.1101/2021.11.23.469660; this version posted November 23, 2021. The copyright holder for this preprint (which was not certified by peer review) is the author/funder, who has granted bioRxiv a license to display the preprint in perpetuity. It is made available under aCC-BY 4.0 International license.

16. Lepelletier D, Maillard JY, Pozzetto B, Simon A. Povidone lodine: Properties, Mechanisms of Action, and Role in Infection Control and Staphylococcus aureus Decolonization. Antimicrob Agents Chemother. 2020 Aug 20;64(9).

17. Lachapelle J-M, Castel O, Casado AF, Leroy B, Micali G, Tennstedt D, et al. Antiseptics in the era of bacterial resistance: a focus on povidone iodine. Clin Pract. 2013 Sep;10(5):579-92.

18. Cieplik F, Jakubovics NS, Buchalla W, Maisch T, Hellwig E, Al-Ahmad A. Resistance Toward Chlorhexidine in Oral Bacteria - Is There Cause for Concern? Front Microbiol. 2019 Mar 22;10:587.

19. Kampf G. Acquired resistance to chlorhexidine - is it time to establish an 'antiseptic stewardship' initiative? J Hosp Infect. 2016 Nov;94(3):213-27.

20. O'Neill J. Tackling Drug-Resistant Infections Globally: Final Report and Recommendations the Review on Antimicrobial Resistance. Rev Antimicrob Resist. 2016;(May).

21. Lee AS, Macedo-Vinas M, François P, Renzi G, Schrenzel J, Vernaz N, et al. Impact of Combined Low-Level Mupirocin and Genotypic Chlorhexidine Resistance on Persistent Methicillin-Resistant Staphylococcus aureus Carriage After Decolonization Therapy: A Casecontrol Study. Clin Infect Dis. 2011 Jun 15;52(12):1422-30.

22. McNeil JC, Hulten KG, Kaplan SL, Mahoney DH, Mason EO. Staphylococcus aureus Infections in Pediatric Oncology Patients: High Rates of Antimicrobial Resistance, Antiseptic Tolerance and Complications. Pediatr Infect Dis J. 2013 Feb;32(2):124-8.

23. Eggers M. Infectious Disease Management and Control with Povidone lodine. Infect Dis Ther. 2019 Dec;8(4):581-93.

24. Higgins JPT, Green S (editors). Cochrane Handbook for Systematic Reviews of Interventions Version 5.1.0 [updated March 2011]. Cochrane Collab. 2011;

25. Moher D, Liberati A, Tetzlaff J, Altman DG. Systematic Reviews and Meta-Analyses: The PRISMA Statement. Annu Intern Med. 2009;151(4):264-9.

26. McGuinness L, Schmidt L. medrxivr: Accessing and searching medRxiv and bioRxiv preprint data in R. J Open Source Softw. 2020 Oct 9;5(54):2651.

27. Wan X, Wang W, Liu J, Tong T. Estimating the sample mean and standard deviation from the sample size, median, range and/or interquartile range. BMC Med Res Methodol. 2014 Dec 19;14(1):135.

28. Walker EM, Lowes JA. An investigation into in vitro methods for the detection of chlorhexidine resistance. J Hosp Infect. 1985 Dec;6(4):389-97.

29. Jakobsen JC, Gluud C, Wetterslev J, Winkel P. When and how should multiple imputation be used for handling missing data in randomised clinical trials - a practical guide with flowcharts. BMC Med Res Methodol. 2017 Dec;17(1):162.

30. Kontopantelis E, White IR, Sperrin M, Buchan I. Outcome-sensitive multiple imputation: a simulation study. BMC Med Res Methodol. 2017 Dec;17(1):2.

31. Viechtbauer W, Cheung MW-L. Outlier and influence diagnostics for meta-analysis. Res Synth Methods. 2010 Apr;1(2):112-25.

32. Viechtbauer W. Conducting Meta-Analyses in R with the metafor Package. J Stat Softw. 2010;36(3). 
bioRxiv preprint doi: https://doi.org/10.1101/2021.11.23.469660; this version posted November 23, 2021. The copyright holder for this preprint (which was not certified by peer review) is the author/funder, who has granted bioRxiv a license to display the preprint in perpetuity. It is made available under aCC-BY 4.0 International license.

33. Biagi M, Giachetti D, Miraldi E, Figura N. New non-alcoholic formulation for hand disinfection. J Chemother. 2014 Apr;26(2):86-91.

34. McGann P, Kwak YI, Summers A, Waterman PE, Lesho EP, Cummings JF. Detection of qacA/B in clinical isolates of methicillin-resistant staphylococcus aureus from a regional healthcare network in the eastern United States. Infect Control Hosp Epidemiol. 2011 Nov;32(11):1116-9.

35. Eick S, Radakovic S, Pfister W, Nietzsche S, Sculean A. Efficacy of taurolidine against periodontopathic species--an in vitro study. Clin Oral Investig. 2012 Jun;16(3):735-44.

36. Knapp L, Maillard JY, Rushton L, Mahenthiralingam E, Stapleton H, Sass A, et al. The effect of cationic microbicide exposure against Burkholderia cepacia complex (Bcc); the use of Burkholderia lata strain 383 as a model bacterium. J Appl Microbiol. 2013 Nov;115(5):111726.

37. Koburger T, Hübner NO, Braun M, Siebert J, Kramer A. Standardized comparison of antiseptic efficacy of triclosan, PVP-iodine, octenidine dihydrochloride, polyhexanide and chlorhexidine digluconate. J Antimicrob Chemother. 2010 Aug;65(8):1712-9.

38. Wasserstein RL, Lazar NA. The ASA Statement on $p$-Values: Context, Process, and Purpose. Am Stat. 2016 Apr 2;70(2):129-33.

39. Amrhein V, Greenland S, McShane B. Scientists rise up against statistical significance. Nature. 2019 Mar 20;567(7748):305-7.

40. Alotaibi SMI, Ayibiekea A, Pedersen AF, Ingmer H, Jakobsen L, Hammerum AM, et al. Susceptibility of vancomycin-resistant and -sensitive Enterococcus faecium obtained from Danish hospitals to benzalkonium chloride, chlorhexidine and hydrogen eroxide biocides. J Med Microbiol. 2017 Dec;66(12):1744-51.

41. Antonelli A, Giovannini L, Baccani I, Giuliani V, Rossolini GM, Pace R. In vitro antimicrobial activity of the decontaminant hybenx compared to chlorhexidine and sodium hypochlorite against common bacterial and yeast pathogens. Antibiotics. 2019 Dec;8(4).

42. Arslan S, Er O, Ozbilge H, Kaya EG. In vitro antimicrobial activity of propolis, BioPure MTAD, sodium hypochlorite, and chlorhexidine on Enterococcus faecalis and Candida albicans. Saudi Med J. 2011 May;32(5):479-83.

43. Azad A, Rostamifar S, Bazrafkan A, Modaresi F, Rezaie Z. Assessment of the antibacterial effects of bismuth nanoparticles against enterococcus faecalis. BioMed Res Int. 2020;2020.

44. Baena-Santillan ES, Piloni-Martini J, Santos-Lopez EM, Gomez-Aldapa CA, Rangel-Vargas E, Castro-Rosas J. Comparison of the Antimicrobial Activity of Hibiscus sabdariffa Calyx Extracts, Six Commercial Types of Mouthwashes, and Chlorhexidine on Oral Pathogenic Bacteria, and the Effect of Hibiscus sabdariffa Extracts and Chlorhexidine on Permeability of the Bacterial Membrane. J Med Food. 2020 Apr;

45. Batubara I, Wahyuni WT, Susanta M. Antibacterial activity of zingiberaceae leaves Essential oils against streptococcus mutans And teeth-biofilm degradation. Int J Pharma Bio Sci. 2016;7(4).

46. Bhatia M, Mishra B, Thakur A, Dogra V, Loomba PS. Evaluation of Susceptibility of Glycopeptide-resistant and Glycopeptide-sensitive Enterococci to Commonly Used Biocides in a Super-speciality Hospital: A Pilot Study. J Nat Sci Biol Med. 2017;8(2):199-202. 
bioRxiv preprint doi: https://doi.org/10.1101/2021.11.23.469660; this version posted November 23, 2021. The copyright holder for this preprint (which was not certified by peer review) is the author/funder, who has granted bioRxiv a license to display the preprint in perpetuity. It is made available under aCC-BY 4.0 International license.

47. Caiaffa KS, Massunari L, Danelon M, Duque C, Abuna GF, Bedran TBL, et al. KR-12-a5 is a non-cytotoxic agent with potent antimicrobial effects against oral pathogens. Biofouling. 2017 Nov;33(10):807-18.

48. Chen H, Tang Y, Weir MD, Oates TW, Gao J, Imazato S, et al. Effects of S. mutans genemodification and antibacterial monomer dimethylaminohexadecyl methacrylate on biofilm growth and acid production. Dent Mater Off Publ Acad Dent Mater. 2020 Feb;36(2):296-309.

49. Chen Y, Liao K, Guo P, Huang H, Wu Z, Liu M, et al. Determining the susceptibility of carbapenem resistant Klebsiella pneumoniae and Escherichia coli strains against common disinfectants at a tertiary hospital in China. BMC Infect Dis. 2020 Jan;20(1).

50. Conceicao T, de Lencastre H, Aires-de-Sousa M. Prevalence of biocide resistance genes, chlorhexidine and mupirocin non-susceptibility in Portuguese hospitals during a 31-years period (1985-2016). J Glob Antimicrob Resist. 2020 Dec; https://doi.org/10.1016/j.jgar.2020.12.010

51. Cowley NL, Forbes S, Humphreys GJ, McBain AJ, Amezquita A, McClure P. Effects of Formulation on Microbicide Potency and Mitigation of the Development of Bacterial Insusceptibility. Appl Environ Microbiol. 2015 Oct;81(20):7330-8.

52. da Silva KR, Damasceno JL, Inacio MO, Abrao F, Ferreira NH, Tavares DC, et al. Antibacterial and cytotoxic activities of Pinus tropicalis and Pinus elliottii resins and of the diterpene dehydroabietic acid against bacteria that cause dental caries. Front Microbiol. 2019;10.

53. Dadpe M, Dhore S, Dahake P, Kale Y, Kendre S, Siddiqui A, et al. Evaluation of antimicrobial efficacy of (Ajwain) oil and chlorhexidine against oral bacteria: An study. J Indian Soc Pedod Prev Dent. 2018;36(4):357-63.

54. Dong L., Tong Z., Lin Y., Tao R., Tian Y., Ni L., et al. Effects of sub-minimum inhibitory concentrations of antimicrobial agents on Streptococcus mutans biofilm formation. Int $\mathrm{J}$ Antimicrob Agents. 2012;35(5):390-5.

55. Duarte B, Pereira AP, Freitas AR, Coque TM, Hammerum AM, Hasman H, et al. 2CS-CHXT Operon Signature of Chlorhexidine Tolerance among Enterococcus faecium Isolates. Appl Environ Microbiol. 2019;85(23):e01589-19.

56. Fernandez-Cuenca F, Gomez-Sanchez MC, Caballero F, Ballesta S, Vila J, Martinez-Martinez $\mathrm{L}$, et al. Effect of Sub-MIC concentrations of biocides on the expression of genes coding for efflux pumps and porins in acinetobacter baumannii ATCC 19606. Clin Microbiol Infect. 2011 May;17.

57. Ferreira CM, da Silva Rosa OP, Torres SA, Ferreira FB, Bernardinelli N. Activity of endodontic antibacterial agents against selected anaerobic bacteria. Braz Dent J. 2002;13(2):118-22.

58. Filho JG, Vizoto NL, Luiza de Aguiar Loesch M, Dias de Sena M, Mendes da Camara D, Caiaffa KS, et al. Genetic and physiological effects of subinhibitory concentrations of oral antimicrobial agents on Streptococcus mutans biofilms. Microb Pathog. 2020 Dec;150:104669.

59. Forbes S, Humphreys GJ, McBain AJ, Dobson CB. Transient and sustained bacterial adaptation following repeated sublethal exposure to microbicides and a novel human antimicrobial peptide. Antimicrob Agents Chemother. 2014 Oct;58(10):5809-17.

60. Freire ICM, Perez ALAL, Cardoso AMR, Mariz BALA, Almeida LFD, Cavalcanti YW, et al. Atividade antibacteriana de oleos essenciais sobre Streptococcus mutans e Staphylococcus 
bioRxiv preprint doi: https://doi.org/10.1101/2021.11.23.469660; this version posted November 23, 2021. The copyright holder for this preprint (which was not certified by peer review) is the author/funder, who has granted bioRxiv a license to display the preprint in perpetuity. It is made available under aCC-BY 4.0 International license.

aureus Antibacterial activity of essential oils against strains of Streptococcus and Staphylococcus. Rev Bras Plantas Med. 2014;16(2):372-7.

61. Furi L, Ciusa ML, Di Lorenzo V, Tocci N, Cirasol D, Oggioni MR, et al. Evaluation of reduced susceptibility to quaternary ammonium compounds and bisbiguanides in clinical isolates and laboratory-generated mutants of staphylococcus aureus. Antimicrob Agents Chemother. 2013 Aug;57(8):3488-97.

62. Ghahramani Y, Yaghoobi F, Motamedi R, Jamshidzadeh A, Abbaszadegan A. Effect of Endodontic Irrigants and Medicaments Mixed with Silver Nanoparticles against Biofilm Formation of Enterococcus faecalis. Iran Endod J. 2018;13(4):559-64.

63. Graziano TS, Calil CM, Sartoratto A, Franco GC, Groppo FC, Cogo-Muller K. In vitro effects of Melaleuca alternifolia essential oil on growth and production of volatile sulphur compounds by oral bacteria. J Appl Oral Sci Rev FOB. 2016 Nov;24(6):582-9.

64. Guerin F, Gravey F, Plesiat P, Aubourg M, Giard JC, Beyrouthy R, et al. The Transcriptional Repressor SmvR Is Important for Decreased Chlorhexidine Susceptibility in Enterobacter cloacae Complex. Antimicrob Agents Chemother. 2020;64(1).

65. Guo J, Li C. Molecular epidemiology and decreased susceptibility to disinfectants in carbapenem-resistant Acinetobacter baumannii isolated from intensive care unit patients in central China. J Infect Public Health. 2019;12(6):890-6.

66. Hajifattahi F, Moravej-Salehi E, Taheri M, Mahboubi A, Kamalinejad M. Antibacterial Effect of Hydroalcoholic Extract of Punica granatum Linn. Petal on Common Oral Microorganisms. Int J Biomater. 2016;2016.

67. Hardy K, Sunnucks K, Gil H, Hawkey P, Shabir S, Trampari E, et al. Increased usage of antiseptics is associated with reduced susceptibility in clinical isolates of Staphylococcus aureus. mBio. 2018;9(3).

68. Hendry ER, Worthington T, Conway BR, Lambert PA. Antimicrobial efficacy of eucalyptus oil and 1,8-cineole alone and in combination with chlorhexidine digluconate against microorganisms grown in planktonic and biofilm cultures. J Antimicrob Chemother JAC. 2009;64(6):1219-25.

69. Hirose N, Kitagawa H, Imazato S, Kitagawa R, Maezono H, Hayashi M, et al. Development of a Cavity Disinfectant Containing Antibacterial Monomer MDPB. J Dent Res. 2016 Dec;95(13):1487-93.

70. Houang ET, Gilmore OJA, Reid C, Shaw EJ. ABSENCE OF BACTERIAL RESISTANCE TO POVIDONE IODINE. J Clin Pathol. 1976;29(8):752-5.

71. Izutani N, Imazato S, Noiri Y, Ebisu S. Antibacterial effects of MDPB against anaerobes associated with endodontic infections. Int Endod J. 2010 Aug;43(8):637-45.

72. Joy Sinha D, K DSN, Jaiswal N, Vasudeva A, Prabha Tyagi S, Pratap Singh U. Antibacterial Effect of Azadirachta indica (Neem) or Curcuma longa (Turmeric) against Enterococcus faecalis Compared with That of $5 \%$ Sodium Hypochlorite or $2 \%$ Chlorhexidine in vitro. Bull Tokyo Dent Coll. 2017;58(2):103-9.

73. Karpanen TJ, Worthington T, Hendry ER, Conway BR, Lambert PA. Antimicrobial efficacy of chlorhexidine digluconate alone and in combination with eucalyptus oil, tea tree oil and thymol against planktonic and biofilm cultures of Staphylococcus epidermidis. J Antimicrob Chemother. 2008 Nov;62(5):1031-6. 
bioRxiv preprint doi: https://doi.org/10.1101/2021.11.23.469660; this version posted November 23, 2021. The copyright holder for this preprint (which was not certified by peer review) is the author/funder, who has granted bioRxiv a license to display the preprint in perpetuity. It is made available under aCC-BY 4.0 International license.

464

74. Koljalg S, Naaber P, Mikelsaar M. Antibiotic resistance as an indicator of bacterial chlorhexidine susceptibility. J Hosp Infect. 2002 Jun;51(2):106-13.

75. Kreling PF, Aida KL, Percinoto C, Duque C, Massunari L, Caiaffa KS, et al. Cytotoxicity and the effect of cationic peptide fragments against cariogenic bacteria under planktonic and biofilm conditions. Biofouling. 2016 Oct;32(9):995-1006.

76. Lacey RW. Antibacterial activity of povidone iodine towards non-sporing bacteria. J Appl Bacteriol. 1979;46(3):443-9.

77. Lavaee F, Ghapanchi J, Motamedifar M, Sharifzade Javidi M. Experimental Evaluation of the Effect of Zinc Salt on Inhibition of Streptococcus mutans. J Dent Shiraz Iran. 2018 Sep;19(3):168-73.

78. Lee SY. Susceptibility of oral streptococci to chlorhexidine and cetylpyridinium chloride. Biocontrol Sci. 2019;24(1):13-21.

79. Li YF, Sun HW, Gao R, Liu KY, Fu QH, Qing SL, et al. Inhibited biofilm formation and improved antibacterial activity of a novel nanoemulsion against cariogenic Streptococcus mutans in vitro and in vivo. Int J Nanomedicine. 2015 Jan;10:447-62.

80. Machuca J, Lopez-Rojas R, Fernandez-Cuenca F, Pascual A. Comparative activity of a polyhexanide-betaine solution against biofilms produced by multidrug-resistant bacteria belonging to high-risk clones. J Hosp Infect. 2019 Sep;103(1).

81. Marcoux E, Lagha AB, Gauthier P, Grenier D. Antimicrobial activities of natural plant compounds against endodontic pathogens and biocompatibility with human gingival fibroblasts. Arch Oral Biol. 2020 Aug;116:104734.

82. Martins ML, Monteiro ASN, Ferreira-Filho JCC, Vieira TI, Guimaraes MBCT, Maia LC, et al. Antibacterial and cytotoxic potential of a brazilian red propolis. Pesqui Bras Em Odontopediatria E Clin Integrada. 2019;19(1).

83. Massunari L, Novais RZ, Oliveira MT, Valentim D, Dezan Junior E, Duque C. Antimicrobial Activity and Biocompatibility of the Psidium cattleianum Extracts for Endodontic Purposes. Braz Dent J. 2017 May;28(3):372-9.

84. McBain AJ, Ledder RG, Gilbert P, Sreenivasan P. Selection for high-level resistance by chronic triclosan exposure is not universal. J Antimicrob Chemother. 2004 May;53(5):772-7.

85. Moraes TS, Leandro LF, Silva LO, Santiago MB, Souza AB, Furtado RA, et al. In vitro evaluation of copaifera oblongifolia oleoresin against bacteria causing oral infections and assessment of its cytotoxic potential. Curr Pharm Biotechnol. 2016 Aug;17(10):894-904.

86. Moreira MR, Souza AB, Soares S, Bianchi TC, De Souza Eugenio D, Lemes DC, et al. EntKaurenoic acid-rich extract from Mikania glomerata: In vitro activity against bacteria responsible for dental caries. Fitoterapia. 2016 Jul;112:211-6.

87. Moreti DLC, Leandro LF, da Silva Moraes T, Martins CHG, Moreira MR, Sola Veneziani RC, et al. Mikania glomerata Sprengel extract and its major compound ent-kaurenoic acid display activity against bacteria present in endodontic infections. Anaerobe. 2017 Oct;47:201-8.

88. Morrissey I, Knight D, Oggioni MR, Curiao T, Coque T, Kalkanci A, et al. Evaluation of epidemiological cut-off values indicates that biocide resistant subpopulations are uncommon in natural isolates of clinically-relevant microorganisms. PLoS ONE. 2014 Jan;9(1). 
bioRxiv preprint doi: https://doi.org/10.1101/2021.11.23.469660; this version posted November 23, 2021. The copyright holder for this preprint (which was not certified by peer review) is the author/funder, who has granted bioRxiv a license to display the preprint in perpetuity. It is made available under aCC-BY 4.0 International license.

505

506

507

508

509

510

511

512

513

514

515

516

517

518

519

520

521

522

523

524

525

526

527

528

529

530

531

532

533

534

535

536

537

538

539

540

541

542

543

544

545

89. Motamedifar M, Khosropanah H, Dabiri S. Antimicrobial Activity of Peganum Harmala L. on Streptococcus mutans Compared to $0.2 \%$ Chlorhexidine. J Dent Shiraz Iran. 2016 Sep;17(3):213-8.

90. Munoz-Gallego I, Infiesta L, Viedma E, Perez-Montarelo D, Chaves F. Chlorhexidine and mupirocin susceptibilities in methicillin-resistant Staphylococcus aureus isolates from bacteraemia and nasal colonisation. J Glob Antimicrob Resist. 2016 Mar;4:65-9.

91. Nakase K, Fukushima H, Yukawa T, Nakaminami H, Noguchi N, Fuji T. Propionibacterium acnes has low susceptibility to chlorhexidine digluconate. Surg Infect. 2018 Apr;19(3):298302.

92. Nazemisalman B, Vahabi S, Yazdinejad A, Haghghi F, Jam MS, Heydari F. Comparison of antimicrobial effect of Ziziphora tenuior, Dracocephalum moldavica, Ferula gummosa, and Prangos ferulacea essential oil with chlorhexidine on Enterococcus faecalis: An in vitro study. Dent Res J. 2018;15(2):111-6.

93. Nicolae Dopcea G, Diguta CF, Matei F, Dopcea I, Nanu AE. Resistance and cross-resistance in Staphylococcus spp. strains following prolonged exposure to different antiseptics. J Glob Antimicrob Resist. 2020 Jun;21:399-404.

94. O'Driscoll NH, Labovitiadi O, Matthews KH, Lamb AJ, Cushnie TPT. Potassium loss from chlorhexidine-treated bacterial pathogens is time- and concentration-dependent and variable between species. Curr Microbiol. 2014 Jan;68(1):6-11.

95. Pal S, Yoon EJ, Park SH, Choi EC, Song JM. Metallopharmaceuticals based on silver(I) and silver(II) polydiguanide complexes: Activity against burn wound pathogens. J Antimicrob Chemother. 2010 Oct;65(10):2134-40.

96. Roedel A, Dieckmann R, Makarewicz O, Hartung A, Noll M, Pletz MW, et al. Evaluation of a Newly Developed Vacuum Dried Microtiter Plate for Rapid Biocide Susceptibility Testing of Clinical Enterococcus Faecium Isolates. Microorganisms. 2020 Apr;8(4).

97. Rosa OP, Torres SA, Ferreira CM, Ferreira FB. In vitro effect of intracanal medicaments on strict anaerobes by means of the broth dilution method. Pesqui Odontol Bras Braz Oral Res. 2002;16(1):31-6.

98. Rose H, Mahenthiralingam E, Baldwin A, Dowson CG. Biocide susceptibility of the Burkholderia cepacia complex. J Antimicrob Chemother. 2009;63(3):502-10.

99. Shani S, Friedman M, Steinberg D. Relation between surface activity and antibacterial activity of amine-fluorides. Int J Pharm. 1996 Apr;131(1):33-9.

100. Sherry L, Millhouse E, Lappin DF, Murray C, Culshaw S, Nile CJ, et al. Investigating the biological properties of carbohydrate derived fulvic acid (CHD-FA) as a potential novel therapy for the management of oral biofilm infections. BMC Oral Health. 2013;13:47.

101. Skovgaard S, Larsen MH, Nielsen LN, Ingmer H, Westh H, Skov RL, et al. Recently introduced qacA/B genes in Staphylococcus epidermidis do not increase chlorhexidine MIC/MBC. J Antimicrob Chemother. 2013 Oct;68(10):2226-33.

102. Suwantarat N, Carroll KC, Tekle T, Ross T, Maragakis LL, Cosgrove SE, et al. High Prevalence of Reduced Chlorhexidine Susceptibility in Organisms Causing Central LineAssociated Bloodstream Infections. Infect Control Hosp Epidemiol. 2014;35(9):1183-6. 
bioRxiv preprint doi: https://doi.org/10.1101/2021.11.23.469660; this version posted November 23, 2021. The copyright holder for this preprint (which was not certified by peer review) is the author/funder, who has granted bioRxiv a license to display the preprint in perpetuity. It is made available under aCC-BY 4.0 International license.

103. Suzuki $Y$, Ohsumi T, Isono T, Nagata R, Hasegawa T, Takenaka S, et al. Effects of a subminimum inhibitory concentration of chlorhexidine gluconate on the development of in vitro multi-species biofilms. Biofouling. 2020 Feb;36(2):146-58.

104. Tambe SM, Sampath L, Modak SM. In vitro evaluation of the risk of developing bacterial resistance to antiseptics and antibiotics used in medical devices. J Antimicrob Chemother. 2001;47(5):589-98.

105. Targino AGR, Dos Santos Jr VE, De Godoy Bene Bezerra F, Rosenblatt A, Flores MAP, Galembeck A, et al. An innovative approach to treating dental decay in children. A new anticaries agent. J Mater Sci Mater Med. 2014 Aug;25(8):2041-7.

106. Tetz G, Tetz V. In vitro antimicrobial activity of a novel compound, Mul-1867, against clinically important bacteria. Antimicrob Resist Infect Control . 2015 Nov;4(1).

107. Touzel RE, Sutton JM, Wand ME. Establishment of a multi-species biofilm model to evaluate chlorhexidine efficacy. J Hosp Infect. 2016;92(2):154-60.

108. Uzunbayir-Akel N, Tekintas Y, Ozturk I, Yilmaz FF, Okeer M, Hosgor-Limoncu M, et al. Effects of disinfectants and ciprofloxacin on quorum sensing genes and biofilm of clinical Pseudomonas aeruginosa isolates. J Infect Public Health. 2020 Dec;13(12):1932-8.

109. Vahabi S, Hakemi-Vala M, Gholami S. In vitro Antibacterial Effect of Hydroalcoholic Extract of Lawsonia inermis, Malva sylvestris, and Boswellia serrata on Aggregatibacter actinomycetemcomitans. Adv Biomed Res. 2019;8:22.

110. Weaver Jr AJ, Shepard JB, Wilkinson RA, Watkins RL, Walton SK, Radke AR, et al. Antibacterial activity of THAM trisphenylguanide against methicillin-resistant Staphylococcus aureus. PLoS ONE . 2014 May;9(5).

111. Xing M, Shen F, Liu L, Wang X, Wang W, Wu X, et al. Antimicrobial efficacy of the alkaloid harmaline alone and in combination with chlorhexidine digluconate against clinical isolates of Staphylococcus aureus grown in planktonic and biofilm cultures. Lett Appl Microbiol. 2012 May;54(5):475-82.

112. Zhang M, Boost MV, O'Donoghue MM, Ito T, Hiramatsu K. Prevalence of antiseptic-resistance genes in Staphylococcus aureus and coagulase-negative staphylococci colonising nurses and the general population in Hong Kong. J Hosp Infect. 2011;78(2):113-7.

113. Zhou Z, Lu Y, Wei D. Polyhexamethylene guanidine hydrochloride shows bactericidal advantages over chlorhexidine digluconate against ESKAPE bacteria. Biotechnol Appl Biochem. 2015 Mar;62(2):268-74.

114. Russell AD. Bacterial resistance to disinfectants: present knowledge and future problems. J Hosp Infect. 1999 Dec;43:S57-68.

115. Platt JH, Bucknall RA. MIC tests are not suitable for assessing antiseptic handwashes. J Hosp Infect. 1988 May;11(4):396-7.

116. Russell AD. Do Biocides Select for Antibiotic Resistance? J Pharm Pharmacol. 2010 Feb 18;52(2):227-33.

117. EUCAST. On recent changes in clinical microbiology susceptibility reports - new interpretation of susceptibility categories S, I and R [Internet]. EUCAST.org. 2021 [cited 2021 Oct 21]. Available from: https://www.eucast.org/newsiandr/ 
118. Prabhakar $\mathrm{H}$, editor. Essentials of neuroanesthesia. London, United Kingdom ; San Diego, CA, USA: Academic Press, an imprint of Elsevier; 2017. 1032 p.

\section{$590 \quad$ Figure Legends}

$591 \quad$ Fig 1. PRISMA flowchart

592 Fig 2. Forest plot of the mean MBC for different species and families of bacteria

593 Fig 3. A scatterplot of study-level estimates of mean MBC over time, for Staphylococci. The size of 594 the points corresponds to the precision (inverse variance) of the study.

595 Fig 4. A scatterplot of study-level estimates of mean MBC over time, for Streptococci. The size of 596 the points corresponds to the precision (inverse variance) of the study. 
Identification of new studies via databases and manual searches

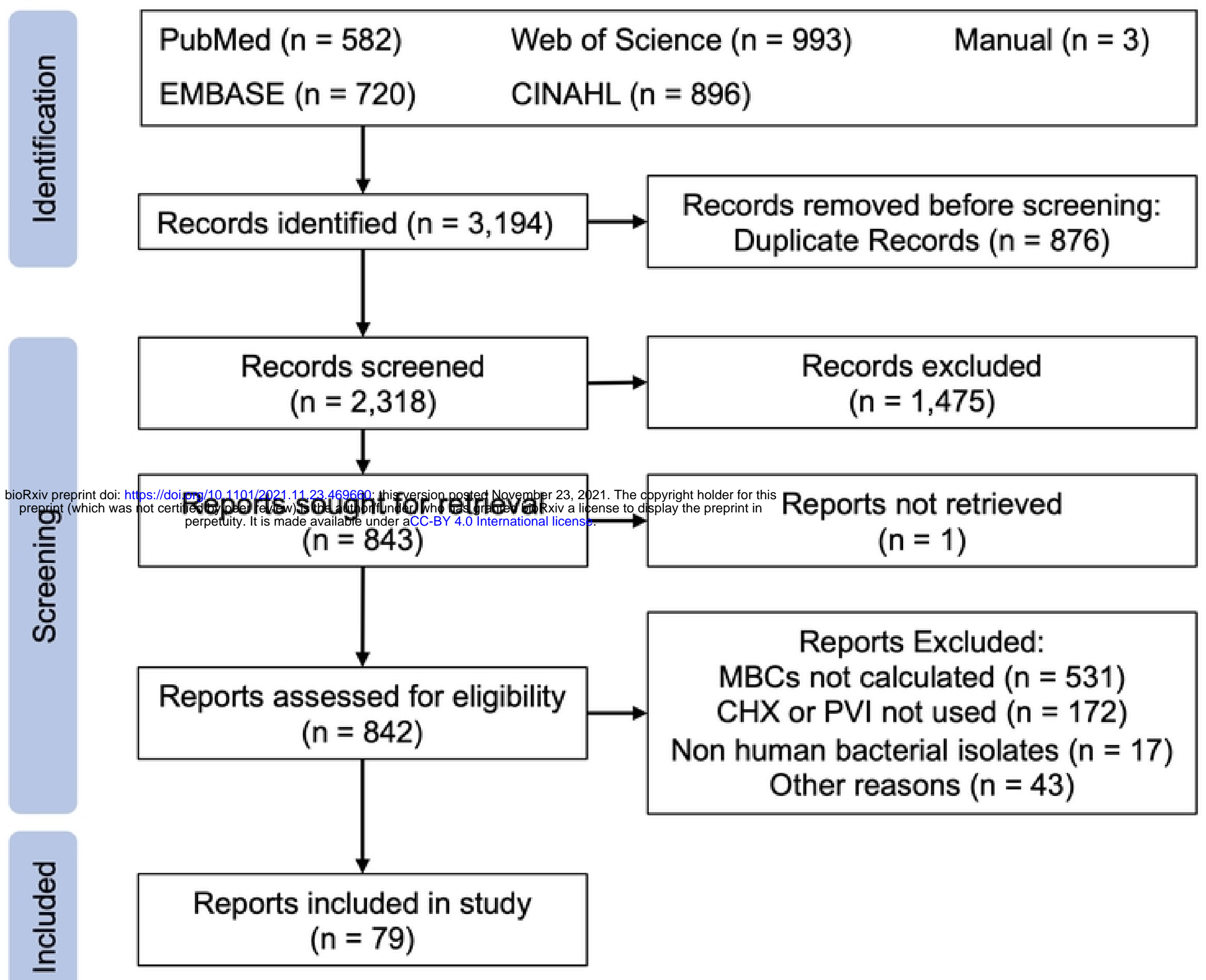


Mean Bacteriocidal Concentration of Chlorhexidine

\section{Bacteria}

\section{Enterococci}

Subtotal $\left(I^{2} 98 \%, p<0.001\right)$

\section{Enteriobacteriales}

Subtotal $\left(I^{2} 96 \%, p<0.001\right)$

Staphylococcus Aureus (MSSA)

Subtotal $\left(I^{2} 95 \%, p<0.001\right)$

\section{Pseudomonas}

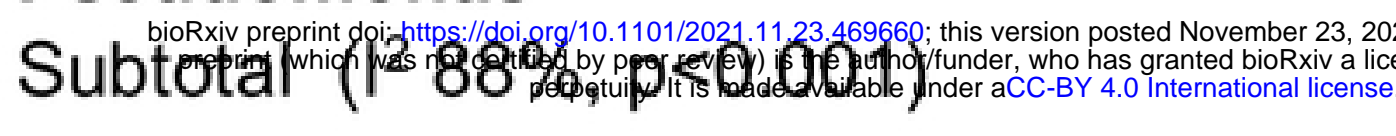

\section{Acinetobacter}

Subtotal $\left(I^{2} 90 \%, p=0.002\right)$

\section{Viridans Streptococci}

Subtotal $\left(I^{2} 99 \%, p<0.001\right)$

\section{Anaerobes}

Subtotal $\left(I^{2} 98 \%, p<0.001\right)$

\section{Actinomyces}

Subtotal $\left(I^{2} 79 \%, p=0.003\right)$

\section{Staphylococcus Aureus (MRSA)}

Subtotal $\left(1^{2} 94 \%, p<0.001\right)$

\section{Coagulase Negative Staphylococci}

Subtotal $\left(\left.\right|^{2} 76 \%, p=0.002\right)$

\section{Pyogenes Streptococcus}

Subtotal ( ${ }^{2}$ incalculable)

Overall $\left(I^{2} 99 \%, p<0.001\right)$
MBC

$(95 \% \mathrm{Cl})$

Weight

(\%)

$15(11,19) 13.36$

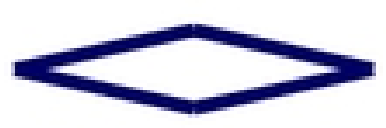

$20(14,26) 6.45$

$6(4,9)$

8.05

$12(5,19) \quad 4.02$

$11(1,22) \quad 2.64$

$10(7,13) \quad 21.62$

$7(1,14) \quad 6.21$

$6(-2,13) \quad 2.23$

$2(1,2) \quad 29.98$
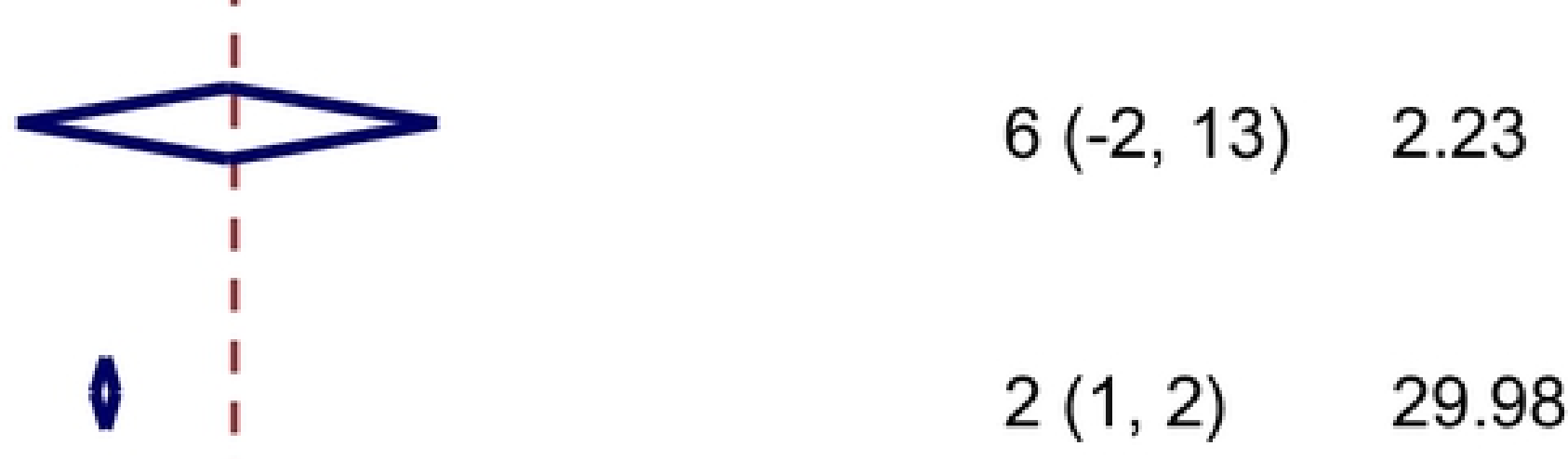

$4(1,7)$

5.32
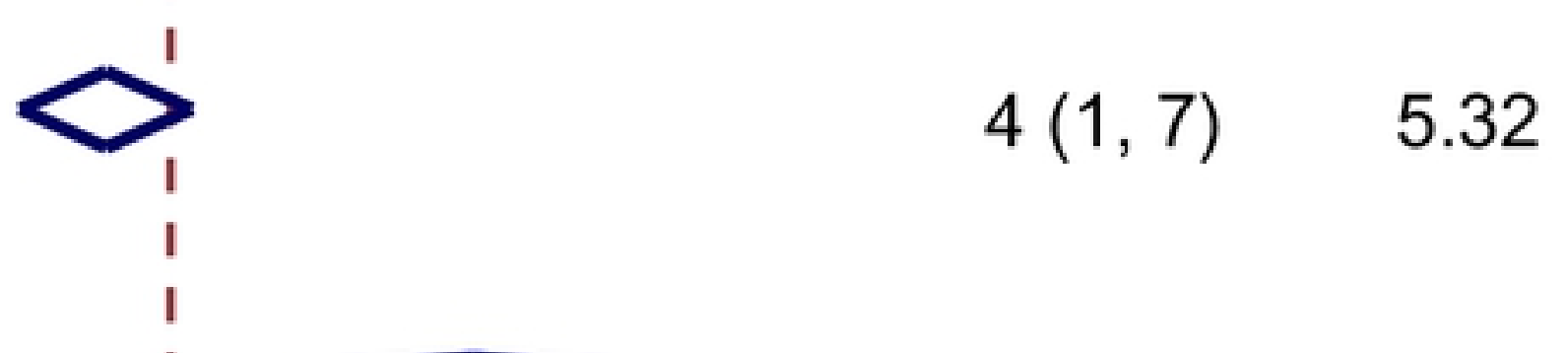

$16(1,31) \quad 0.12$

$6(6,7)$

100

Fig 2 
Mean Bacteriocidal Concentration of Chlorhexidine for Staphylococci over time

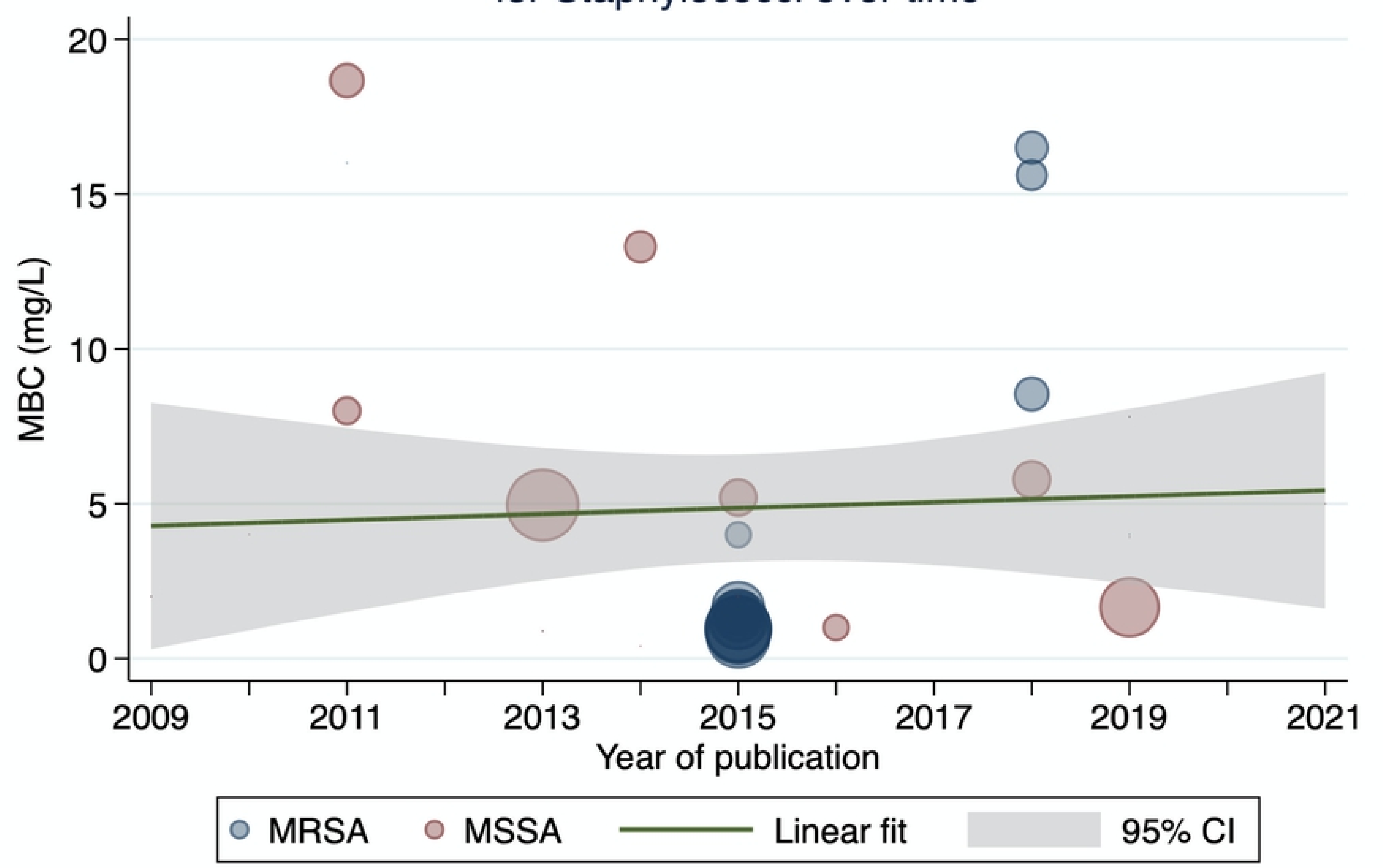

Fig 3 
Mean Bacteriocidal Concentration of Chlorhexidine for Streptococci over time

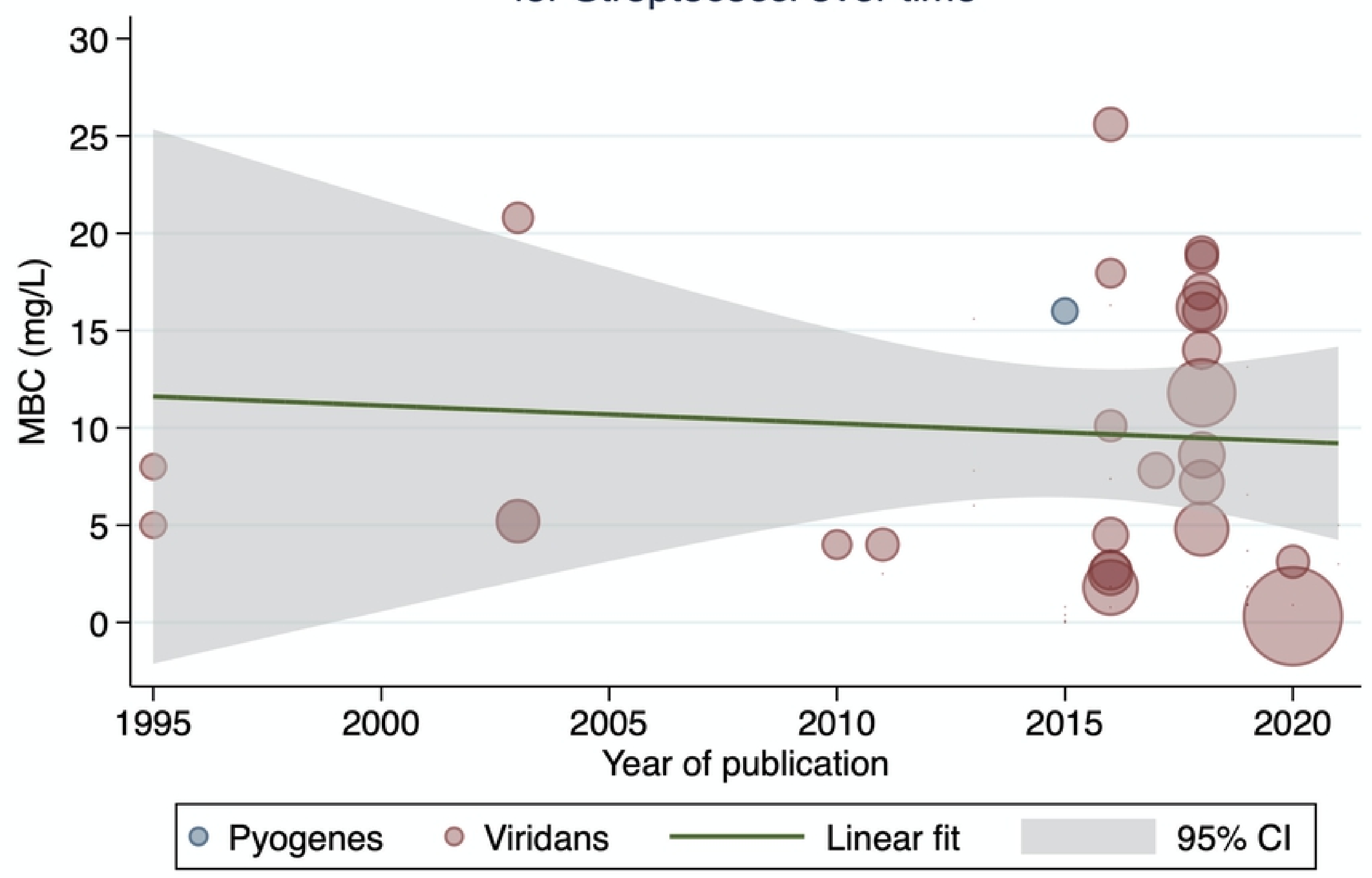

Fig 4 